to time. We gets whipped with a velvet whip and there's free dental care and always a fiddler case your feets gets restless."

"You see, Mr. President. They need someone to guide them through this world of woe or they'll hurt themselves."

"I'll certainly consider your views when I make my decision, Mr. Porke. Well, I have to go now. And thanks for contributing to the war chest, Mr. Porke. Buying these bonds and all."

"Sure, Lincoln, anything you say." Goes to the window. "Hey I think the escort Lee sent up has arrived. Look, Lincoln, I'm throwing a little shindig for Mr. and Mrs. Jefferson Davis. Why don't you come down? I'd like to get you two together for one day. Take time off from the war."

"You can arrange that, Mr. Porke?"

"I can arrange anything. They called my father God's God, Mr. President. Although you may hate Lee's flag and Lee hate yours, everybody salutes our flag. I can arrange anything on earth and soon," Porke says looking skyward, "in the heavens too."

Uncle Tom and Lincoln exchange surprised glances as Porke begins a strange maniacal incongruous laugh. Thunder and lightning emblazon the sky.

Lincoln and Uncle Tom exit as Porke is left behind, rocking on his heels, tears streaming down cheeks, laughing wildly.

\title{
Visions of Love and Manliness in a Blackening World: Dramas of Black Life from 1953-1970
}

At present, two types of drama are being discussed and practiced by Black dramatists of America. One type has been designated "Black Arts" drama, which includes such variations as Black Revolutionary drama, drama of Black Experience, and Ritual drama. No particular label has been applied regularly to the other style of drama. For convenience, I call it "Traditional" -not to imply that it is old-fashioned or archaic, but to suggest that it continues the traditional or habitual practice of emulating styles of American drama rather than seeking styles uniquely identifiable with Black culture.

Black dramatists and critics have propounded simplified distinctions be-

This article is taken from a lecture at the Fifth Annual Institute for Afro-American Culture, The University of Iowa, 1973. 
tween Black Arts drama and Traditional drama. Black Arts drama, it is said, is written about Black people, is intended to educate a Black audience to its need for liberation, and should derive its style or technique from Black culture. Some disparaging critics contend that such drama is racist because it focuses solely on the needs of Black people, that the language is obscene, that the life-style of the characters is squalid, and that the tone is excessively militant.

Such deprecatory descriptions, however, are biased. First, even if the generalizations were valid, racism, obscenity, squalor, and racial hatred can be found in many White-authored plays which are respected in American theater. Despite its present respectability in the history of American theater, Tobacco Road, when compared with plays of its day, must be adjudged as vulgar in language and morality as anything ever written by a Black dramatist. Although a White dramatist would hesitate to castigate Blacks overtly in plays of the 1970 's, in the early years of this century American theater staged and endorsed Thomas Dixon's vilifications of Black people. And I am certain that Tennessee Williams has not been concerned whether Black people find matters of interest to them in the White South which he delineates in such plays as The Glass Menagerie and A Streetcar Named Desire. Do not misunderstand; I do not suggest that racism, obscenity and vulgarity (however defined), and hatred are desirable or necessary characteristics of drama. But I do insist that, if the American public and critics have praised White plays containing such elements, it is racist and hypocritical for the same audience to condemn Black plays merely because such elements exist. Furthermore, as I will show later in this paper, these negative qualities are not in the work of all Black Arts dramatists; therefore, they are not essential to the definition of Black Arts drama.

A simplified description of Traditional drama is that, although it may be written about Black people, it does not propose the education of a Black audience as its major purpose-it may seek merely to "entertain," in the very broad sense of the term which includes any creative effort to elicit aesthetic pleasure from an audience. Furthermore, Traditional drama is written for an audience which is presumed to be raceless (or predominantly White).

These, as I have said, are simplified but popular definitions of Black Arts drama and Traditional drama. I wish, however, to question the validity of such distinctions. Is Black Arts drama the only style which is valuable for, and relevant to, Black people? Are the visions of Black Arts playwrights irreparably different from those of the Traditionalists? Is Black Arts drama so dissimilar from the Traditional that one can never be mistaken for the other? Such questions must be answered if one is to describe intelligently the state of Black drama today. 
In order to focus on specific examples within the all-too-brief space afforded for this paper, I shall restrict myself to the work of eight of the best-known playwrights of the past two decades: Louis Peterson, Lorraine Hansberry, James Baldwin, Imamu Amiri Baraka, Ed Bullins, Lonne Elder, Charles Gordone, and Melvin Van Peebles. Each of these has earned significant critical attention in professional theater for work which purports to examine Black life seriously. As a group they span the last two decades: Peterson and Hansberry emerged during the Fifties; Baldwin and Baraka, in his early work, reflect the early Sixties; and Van Peebles is a center of attention-and controversy-during the early Seventies. These eight dramatists also personify the divergent concepts which I have identified: Peterson and Hansberry have been identified with Traditional drama, whereas Baraka, Bullins, and Van Peebles have been advocates of Black Arts drama.

To focus the analysis even more sharply, I shall examine the work of the dramatists in relation to three major questions or issues: What is the "good life"? What is love? And what is manhood or manliness? I will not evaluate the plays themselves, nor will I evaluate the dramatists' answers to these questions. Instead, I shall examine only the dramatists' positions on these issues, which must be considered universal even when they are drawn from the lives of Black people.

That is, these issues define the consciousness of mankind. They represent the questioning which differentiates conscious behavior from instinct. Prophets, philosophers, poets, psychologists, sociologists in all nations and all races have puzzled over answers to these questions. Surely, then, these issues cannot cease to be universal when the answers are drawn from the experiences of Black Americans. To deny their universality merely because they are answered in respect to the Black experience would presume that the Black American is a phenomenon whose life-experience, judgments, and values lie outside the human experience. Please notice that I state "outside the human experience," not merely "different from the White experience." If Black experiences, values, and judgments are merely different from those of Whites, then any definition of universality must be sufficiently broad to include both Black and White modifications of and variations from the norm. Black values can be judged meaningless as universal values only if Black people are adjudged nonhuman.

Since the questions themselves are universal, the answers can be considered unique only in the sense that they reflect the attitudes of a particular group at a particular time and a particular place. In this group, as in any other in which individuals are permitted to articulate their thoughts, opinions will differ. With this in mind, let us see how the best-known Black American dramatists of the past two decades have defined the good life, love, and manliness. 
In the 1950's, both Louis Peterson (Take a Giant Step, 1953) and Lorraine Hansberry (A Raisin in the Sun, 1959) presented "middle-class" families in Northern settings. I am not using the term "middle-class" pejoratively, nor am I equating "middle-class" with professional status. In the social structure of Black Americans, the middle-class has included many individuals whose economic and occupational status sets them outside the limits traditionally drawn for the middle-class in White American society. For example, both Richard Wright and Imamu Amiri Baraka have identified postal clerks as middle-class. Jessie Fauset and Chester Himes have included seamstresses and educated factory workers among the middleclass. In this paper, therefore, I shall identify as middle-class any Black American who has a stable job, a residence away from his place of employment, formal education and respect for the value of education, and aspiration to standards traditionally ascribed to middle-class life, such as marriage, property, and sobriety.

Judged by these criteria, the Black family of Peterson's Take a Giant Step is obviously middle-class. The father is a bank clerk, who has moved his family from a Black ghetto in order to find better living conditions for his children. One son is in college; the other is preparing to attend. Similarly, even though the Youngers of Hansberry's A Raisin the Sun proudly describe themselves as descendants of working people, even though Walter Lee Younger is a chauffeur and his mother is a domestic worker, his sister Beneatha is a college student, aspiring to be a doctor, and Walter Lee's son is attending school-probably to prepare himself for a job better than his father's. Walter Lee himself frets about his role as chauffeur; he wants to own a business and to provide his wife with the luxuries which he associates with middle-class Whites.

Even though both Peterson and Hansberry agree that Blacks and Whites have similar character traits and similar values, they are ambivalent about social interrelationships. Take a Giant Step is the story of teen-aged Spencer Scott's search for maturity in a predominantly White society. Angered and embarrassed by a White teacher's description of slaves as morons, Scott, the only Black in the class, rebels against authority by challenging her. When he continues his defiance of convention and authority-his movement toward manhood-by smoking a cigar, he is expelled from school. Feeling betrayed by his classmates, who did not defend him and who do not invite him to their parties now that girls attend, Scott seeks companionship and maturity in a romantic or sexual relationship with a Black woman. Once again, he fails to prove his manhood. One woman rejects him because she wants a man on whom she can lean, and his experience with a prostitute produces juvenile panic. Returning home, Scott is further repressed by his parents, who inform him that, because he is a Negro, he can never be a 
man. His mother says that he has no right to talk back to White women, "no matter what they say or do. If you were in the South you could be lynched for that and your father and I couldn't do anything about it. So from now on my advice to you is to try and remember your place." his own humiliations as a lone Negro who ignores insults in order to retain his job, Spencer's father also demands that he apologize. Spencer, however, has gained a new awareness of manhood. Comforted by Christine, an older woman who initiates him into the sexual experience which he presumes to be one evidence of manhood, Scott decides to be a man. He will accept his isolation from White companionship as a reality, will renounce all interest in childhood games, will return to school, and will prepare himself for college. Unanswered is the question, How worthwhile is all that effort when, at best, he can merely duplicate the experience of his father, who daily denies his manhood in order to retain his job?

Peterson had no positive answers about maturity or the good life. Writing during a decade which emphasized the importance of integration, he suggested that Spencer Scott would never become integrated socially. To free himself from the horrors of ghetto housing, Spencer might live in a White neighborhood. To pay for the house and other comforts, he might work at a White job. But he would be alone, as his parents were alone.

Visions of love in Take a Giant Step are slightly more positive. Certainly, Spencer's mother and father love each other-even though the father occasionally bullies his family in a futile effort to reaffirm his eroded manhood. The rest of the Black world seems populated by prostitutes and by young wives seeking escape from the restrictions imposed by poverty. But there is at least a Christine, who compassionately can offer and receive love.

Except for his skin color, Spencer Scott is a stereotypically middle-class American male youth. He plays baseball, collects stamps, and experiences conventional difficulties with sexual maturing. His problem is not that he is fundamentally different from White American boys, but that they reject him. His definitions of the good life and of his manhood must be phrased in terms of this rejection. If his definition is not "universal"-whatever that may imply-the fault is not his but that of a society which refuses to see him as a person capable of universality. Spencer's society, Peterson concludes, is a separate society-not because Spencer wants it that way but because that is the way of life in America.

In A Raisin in the Sun, Lorraine Hansberry even more consciously emphasized the correspondences between Whites and Blacks even though she too assumed an ambivalent stance in regard to the social integration of the two groups. Although he can respond to African rhythms when he is intoxicated, Walter Lee Younger typifies the upward-moving American male. He honors 
ruthless capitalism; castigates Blacks for lack of shrewdness in business; denounces wealthy people who consider themselves superior because of their wealth, but is willing to fawn before the wealthy if they will assist him; and desires to provide his son with a life better than his. His wife Ruth is almost a stereotypic American heroine of soap opera; and, prior to the interest in African culture which characterizes her behavior during the play, Beneatha has embraced the frivolous values and activities frequently associated with immature and pampered American college students. Like her children, Lena Younger has adopted traditionally affirmed American values. Hers belong to the Puritan ethic: decency, Christianity, and hard work. Significantly-and ironically-when Mr. Lindner, a White man, tries to dissuade the Youngers from moving into Clybourne Park by recounting the attitudes of the Whites in the neighborhood, he is merely describing lighter-skinned Youngers-"hard working, honest people who don't really have much but those little homes and a dream of the kind of community they want to raise their children in." 2

Despite their similarities to Whites, the Youngers, however do not seek social integration. Lena purchases a home in a White community, not because she wants to live among Whites, but because it is a wise investment in her effort to improve the lives of her children. (Comparable houses in Black neighborhoods cost more.) As Walter Lee says when he affirms the Youngers' determination to enter the Clybourne Park community, "We don't want to make no trouble for nobody or fight no causes-but we will try to be good neighbors."3

During the play Walter Lee struggles to define himself as a man. Resenting his economic dependence upon his White employer and his mother, he defines manhood as the ability to support and provide luxuries for a family -a concept certainly accepted by most White Americans. Although his mother defines manhood differently, she too espouses an ideal shared by other Americans. She insists that a man must be the moral leader of his family: he must make the correct moral decisions and must possess the strength to require his family to accept those decisions. At the end of the play when Walter Lee, entrusted with authority, affirms the family's determination to move from the ghetto, the audience hopes-and perhaps believes-that Walter Lee is beginning to accept his mother's concept of manhood-at least to the extent of refusing to barter self-respect for money. But an ironic question must be raised: Has Walter Lee actually converted to a new ideal, or does he believe that he is submitting to his mother's will?

Lorraine Hansberry affirms the need for an existence of love within a Black family. Although Walter Lee quarrels with his wife and she suspects that he may be seeking companionship with another woman, there is little doubt that Walter Lee and Ruth love each other just as much as Lena and 
Big Walter loved. When Beneatha berates her brother for permitting himself to be swindled, her mother reminds her,

Child, when do you think is the time to love somebody the most; when they done good and made things easy for everybody? Well then, you ain't through learning-because that ain't the time at all. It's when he's at his lowest and can't believe in hisself 'cause the world done whipped him so. ${ }^{4}$

Perhaps most significant of all is the fact that, despite the quarrels, the play abounds with scenes of playful affection between Ruth and her son, between husband and wife, between brother and sister, and between Lena and her children. Clearly, although the love is sometimes strained, it always exists as an unconscious refutation of those armchair sociologists who proclaim that the oppressions of life necessarily prevent love within a Black family.

The attitudes of Peterson and Hansberry seem characteristic of Black literature as well as Black drama of the 1950's. Because the decade emphasized integration, Black writers and politicians often stressed the similarities between Blacks and Whites just as self-consciously as Chesnutt and Dunbar had during the 1890's or Jessie Fauset during the 1920's. Consequently, "the good life" in drama of the Fifties was that defined for White America, differing from that standard only to the extent to which the efforts of Blacks were modified by Whites.

On the other hand, to dispel the notion that Blacks sought integration merely because they desired to live with Whites, Black writers emphasized their desire for freedom of opportunity rather than social relationship.

The new political stance adopted by Blacks during the 1960's could be expected to produce new visions in drama. By 1964, when James Baldwin's Blues for Mr. Charlie and LeRoi Jones' Dutchman appeared, the passive boycotts of the late Fifties had been supplanted by the still "nonviolent" but more aggressive sit-ins of the 1960's. Although "Black Power" was not yet a household slogan, a more militant rhetoric of confrontation had developed. The new attitudes are reflected in the best-known plays of Baldwin and Jones in the 1960's.

Like the plays of Peterson and Hansberry, Blues for Mr. Charlie and Dutchman were written for White audiences; hence, they must be categorized as Traditional drama. In both plays, the Black characters are more willing than earlier protagonists to challenge White characters verbally; but they passively reject physical confrontation. It is the Whites who initiate the violence. Spencer Scott's parents had insisted that he should not challenge White authority; Walter Lee Younger's verbal rejoinders to Mr. Lind- 
ner had been determined but polite. In contrast, in Blues for Mr. Charlie, young Richard Henry deliberately provokes and wins a verbal confrontation with the White antagonist, who then kills Henry and is acquitted. In Dutchman, Clay, when sufficiently antagonized by Lula, responds with a violent rhetorical attack which causes Lula to kill him. In Black drama of the early 1960 's, therefore, manhood seems determined partly by the willingness of Black males to challenge White authority even if that challenge is suicidal.

Focusing solely on this dimension, many playgoers-both Blacks and Whites-have denounced such dramas as militant, radical, revolutionary, melodramatic diatribes of racial hatred. Actually, however, Blues for Mr. Charlie and Dutchman are surprisingly similar to the plays of Peterson and Hansberry. Both examine the dilemma of middle-class Blacks. Clay, the protagonist of Dutchman, wears Ivy-League clothes and lives in New Jersey-outside Harlem. Although Richard Henry, in Blues for Mr. Charlie, has been a professional entertainer, his father, who may be the actual protagonist, is an educated minister sufficiently affluent to support Richard until he recovers from his Northern experience.

In both plays, the similarities of Blacks and Whites are stressed. For example, in Blues for Mr. Charlie, the weaknesses of the White characterslust, lack of moral strength-are the weaknesses for which Black Americans stereotypically have been demeaned. And the strengths of the Black characters-godliness, courage, braggadocio-are the strengths for which White Americans traditionally have been praised.

Like Peterson and Hansberry, Baldwin adumbrates the importance of an integrated society without suggesting that Blacks seek a social relationship. Through his stage directions, Baldwin symbolizes the interrelationship of the two groups. While the Blacks are on stage, White characters appear as shadows in the background. While Whites are on stage, they hear the services from a Black church. Nevertheless, the Blacks do not seek social integration. Even though Meridian Henry wishes to improve the status of Blacks in the community and accepts Parnell, a White liberal, as a friend, it is Parnell and Britten, the White antagonist, who actively promote racial interrelationships by their quests for Black women.

In Dutchman also, emphasis is placed upon the similarities in the values of middle-class Blacks and Whites, a theme frequently missed by those spectators who think of the author only as a spokesman for Black nationalism and separatism. When Lula, a White liberal-temptress, ridicules Clay because he practices European fashions in attire and culture, Clay defends his right to select his own values: "Let me be who I feel like being ... it's none of your business. . . . You great liberated whorel"5 he shouts in a manner highly reminiscent of Spencer Scott's denunciation of his ignorant White 
teacher, who sits on a desk to tantalize her male students by displaying her underwear. During this stage of his life, Jones did not insist that absolute and irreconcilable differences distinguish Blacks from Whites. Instead, he protested against Whites' assumptions that they have a monopoly upon particular values and that they have the right to stereotype and control all Blacks according to their ideas of what a non-White should be.

Like Baldwin, Jones suggests that it is Whites rather than Blacks who actively seek social interrelationships. Clay is attracted to Lula when he sees her through a window of a subway, but Lula initiates the seduction.

Although Jones has stated that Dutchman can be discussed as a play about a Black man and a White woman, to restrict analysis to the Black male-White female relationships is to ignore a dimension clearly suggested not merely by Dutchman but also by The Toilet and The Slave, which he wrote during the same period. Each of the three suggests an indebtedness to Expressionism. As a literary term, "Expressionism" was first used to label the work of a group of German writers who, at the time of World War I, revolted against Naturalistic methods in their expression of the problems of mankind. In reference to drama, "Expressionism" describes a reliance upon abstraction rather than upon a strict pattern of dramatic principles. The German Expressionists expressed or objectified ideas and emotions. Because they proposed philosophical attitudes, they designed either characters who represent social groups or characters who are to be identified with dynamic social ideals. As Ernst Toller, a leading Expressionist, explained:

In style, expressionism was always pregnant, almost telegraphic, always shunning the peripheral and always probing to the center of things. In expressionistic drama man is no accidental private person. $\mathrm{He}$ is a type posited for many and ignoring the limits of superficial characterizations. ${ }^{6}$

Each of the three plays which Jones wrote during 1963-65 Expressionistically presents the tragic involvement of sensitive, middle-class Black youth with Euro-American culture. Ironically, the three supposedly vitriolic plays also remind one of Peterson's Take a Giant Step, not merely in the authors' distinction between the cultural level of the protagonist and that of other Blacks but also in the refusal to resolve the problem of the protagonist.

In The Toilet, Karolis, representative of White Euro-American culture and ideals, attempts to seduce Ray, a popular Black youth nicknamed "Foots" by his gang. The Black gang (the Black masses), coarser and more violent than Ray, insists that he physically reject Karolis. As Ray hesitates, 
Karolis reminds him that Ray privately has responded-not as "Foots," the gang leader, but as Ray, whom the gang does not know. When Karolis threatens Ray, others in the gang beat Karolis to the ground. After all have left, however, Ray returns to comfort Karolis by holding him. In Dutchman, too, the Black protagonist responds to a seduction initiated by a representative of Euro-American culture. In that play, however, rather than being pressured by his society to attack, the protagonist himself recognizes the need for a physical confrontation with White culture. Like Foots, however, the middle-class protagonist of Dutchman refuses to attack. Instead of performing cathartic murder, he says, he would rather write a poem. Neither love nor manhood can be achieved in such situations, for, in both plays, the protagonist is suspended between a Black world (culture) which he detests and a White world (culture) which tantalizes him but limits his stature.

A comparable pattern exists in The Slave. A Black revolutionary leader visits his former wife and her husband. In combination, the White couple represent the emotional and intellectual aspects of Euro-American culture. Despite his role as leader of an army committed to destroy that culture, Walker Vessels feels closer emotionally and intellectually to that culture than to the Black troops, whose values he despises. Although he can organize others to rebel against that culture, individually Walker Vessels cannot initiate action. Like Ray, he strikes only when threatened. Like Clay, he substitutes rage for action. One wonders whether he, like Clay and Richard Henry, would mutely accept execution by Whites.

Critics of the time described Jones' three plays as violent and racist. Yet the three protagonists-different only in age and role-resemble Spencer Scott. Rejected by a world-a culture-which fears their masculinity, Jones' protagonists cannot find identity among their own people. Like Scott, the Black protagonists withdraw from the integrated society only because of social pressure or social rejection; if anything, Jones' protagonists desire total integration even more consciously than Scott does.

After 1965, however, Black dramatists no longer propose integration. Whether they write Traditional or Black Arts drama, they seem to accept the moral of Jones' trilogy: regardless of anyone's desires, Black life is and will remain separate from White life. Integration, they suggest, inevitably exploits Black people.

The new vision appears vividly in The Great Goodness of Life (1966) by Jones, now writing as Imamu Amiri Baraka. Perhaps the most artistic of his published examples of Black Revolutionary drama, Great Goodness of Life presents Court Royal, a Negro postal worker who is arrested and charged with harboring a murderer. Bewildered by the accusation, since he knows that he would never consciously violate a law of America, Court 
Royal reluctantly agrees to expiate his crime by symbolically executing the murderer. At the moment of execution, a cry of "Papa" informs the audience that the middle-class Negro has been tricked into destroying his rebellious offspring. In the drama neither manhood nor love exists. Court admits his weakness:

“. . please, I never wanted anything but peace ... please, I tried to be a man. I did. I lost my ... heart ... please it was so deep, I wanted to do the right thing, just to do the right thing. I wanted ... everything to be ... all right." "7

Having surrendered his manhood to a desire for peace in the manner of Ray and Clay before him, Court Royal saves his own life but sacrifices his son's in order to gain approval from White society. Objectively judged, there seems merely a difference of degree between Jones' Expressionistic portrayal of a parent who sacrifices his child's life to society and Peterson's more individualized study of parents who require their child to repudiate truth and self-respect.

Since 1965, Black dramatists of Black life have focused on the same themes of love and manhood which dominated Afro-American drama in the early 1950's and '60's. Love and manhood, you may recall, is what Clay and Lula, in different ways, said that Dutchman was all about. And even though the vision of a separate society assumed bleaker and more violent hues in the late Sixties, the vision itself had been foreshadowed in such earlier dramas as Baldwin's The Amen Corner, first performed professionally in 1965 but written during the 1950's.

The Amen Corner, like Baldwin's first novel, is set in a Black church. In the drama, Baldwin virtually ignores any relationship between White society and Black life. The Amen Corner offers no protest sermon for a White audience. If any comparisons are to be drawn between Black people and Whites, they must be based upon the experience which Black and White spectators bring to the theater; Baldwin writes about the people he knows as though no others need be considered. Without reference to the values of Western society, Baldwin diagrams the good life and the need for human love.

Sister Margaret, a minister, fanatically denounces all pleasures of the flesh and demands absolute moral perfection from her congregation. Resenting her tyranny and lack of compassion, her parishioners-and even her son David-rebel against her authority. Her control is further threatened when Luke, her dying husband, returns and forces her to face the truth of their past. When their second child died, neither Margaret nor Luke had. 
strength enough to offer the love which the other needed. Because she blamed him, not their poverty, for the child's death, she could not comfort him in his grief. Because he derived no comfort from her, he turned to drink and, thus, became even less able to provide the support she needed. Requiring security, she fled to God, whom, in her own need, she identified as One who forbade the human involvement which had precipitated her troubles. When Luke forces her to scrutinize herself honestly, she realizes that she wants to be a woman and wife more than anything else, just as Luke, a wandering musician, has always known that a career cannot compensate for the absence of love. Margaret's awareness develops too late. Luke dies, and, humanized by her love, Margaret loses her power to preach about a god of Wrath. Ironically, she loses both husband and congregation at the very time at which, human and compassionate, she is the most capable of helping both. The only hope in the play remains with David, who leaves the church, no longer in flight from repression but in search of a way-through music-to express, and thus assist, Black people.

Though written in the 1950's, The Amen Corner, I believe, is as clear an example of Black Arts drama as anything written by Ed Bullins, well-known as a theorist and practitioner of that concept in the 1960 's. In his dramas about Black life, Bullins generally suggests a vision by picturing the absence of vision. Love is a ruse for stealing a wife from a benefactor; it is adultery and lesbianism; it is abuse and betrayal. Manhood is the practice of Walter Younger's false dream-to exploit others before they exploit you. And there is no good life. Bullins' vision is at best a dream which will never materialize, a nostalgia for what might have been. I have said that Black Arts drama assumes the responsibility of educating Black people to awareness of their needs for liberation. Bullins' dramas are educational primarily in the sense that they depict the sordid realities which must be transformed if Black life is to improve. Bullins presents few illustrations of the positive qualities which should be affirmed and practiced by Black people. Perhaps the only character who stands as a positive example rather than a negative one is Cliff Dawson. Although he may have been dishonorably discharged from the navy and though he commits adultery, abandons women, and abuses his wife, he, nevertheless, is capable of compassion for family, as he demonstrates when he kills in order to protect his young nephew from a brawl which will end in death or prison, or when he reveals sympathy for the adulterous wife and half-brother who have betrayed him.

The cycle of Bullins' plays is a world of squalor as lurid as that of William Faulkner or Erskine Caldwell. In Clara's Old Man, a middle-class youth believes that he can seduce a young woman in the absence of her "old man," whom he carelessly assumes to be either her father or her husband. His 
fling is aborted by his discovery that he has stumbled into a lesbian relationship in which he is easily outwitted by the "old man," who orders him beaten.

In Goin' a Buffalo, a pimp-racketeer-murderer planning a robbery to finance a new start in Buffalo befriends a young man whom he met in prison. The man, whom he trusts and treats as though he were a brother, betrays him to the police, steals his money and his wife, and appropriates his dream of a new life in Buffalo.

In In the Wine Time (1968) the central character is Cliff Dawson, a former sailor, who has enrolled in school in order to elevate himself above the squalor of the ghetto, where love is a euphemism for lust, where husband and wife talk past each other instead of to each other, and where lovers substitute humiliation for respect. Cliff teaches his wife's nephew to dream of beauty in a world beyond the ghetto. When the nephew becomes involved in a drunken brawl with a neighborhood youth, Cliff, to protect his nephew, kills the youth and goes to jail.

In New England Winter continues the story after Cliff has been released from prison. With his half-brother Steve Benson and two others, Cliff plans a bank robbery, which will earn all of them sufficient money for a new start. Steve persuades himself that he will return to New England, to a girl whom he deserted. The robbery is aborted when Steve kills a gang member to prevent his revealing what Cliff already knows: that, while Cliff was in jail, Steve seduced Cliff's wife, made her pregnant, and then involved her with another man so that Cliff would not suspect Steve's guilt.

The Duplex is set two years later. Steve, attending school, has become his landlady's lover. When the landlady's husband returns to abuse, rob, beat, and rape his wife, Steve is impotent to act despite his protestations of love. Later, assuring himself that he has become sufficiently manly to protect her, Steve openly takes her as his lover. When the husband again returns, he beats Steve and drags his wife away. And the life of cards and whiskey goes on.

One may argue that these characters are not from the same social class as those in The Amen Corner, but the class difference-if it exists-seems unimportant. Bullins' characters live in an all-Black world in which survival requires one to assume everyone else to be his enemy. Education is judged desirable, but crime provides more money. Whites who flutter through this world are not villains but alcoholics, dope addicts, prostitutes-as easily deceived as are the Blacks. Like Baldwin, Bullins offers no problem to be solved by a White audience. If there is any significant difference between Baldwin and Bullins, it is that, whereas Baldwin rationalizes the behavior of a wandering musician who drinks liquor excessively, Bullins spares no feelings in portraying his protagonists as alcoholics, murderers, hypocrites, ex- 
ploiters, bullies, and criminals who betray one another and even themselves. Pathetically, they succeed neither in self-improvement nor even in the crimes they attempt. The very multiplicity of examples of lack or loss of vision, I believe, suggests the need for vision and; thus, implies Bullins' educational thesis-that such a world is salvageable only if it is supplied with visions of love, manhood, and a good life.

Neither Lonne Elder nor Charles Gordone has been identified with Black Arts drama as clearly as Bullins has been. Both are assumed to be writing Traditional drama. Yet their works resemble the Black Experience dramas by Bullins.

Elder's Ceremonies in Dark Old Men (1969) recounts the story of a Black family's battle with reality. After his wife's death, a father and his two grown sons allow the daughter of the house to support them until the daughter refuses. Unable or unwilling to get jobs, the males of the household embark upon a swindle of the Black community. They rationalize their behavior by insisting that exploitation of ghetto-dwellers is justifiable if the exploiters are also Black ghetto-dwellers. After initial successes, they fail in their schemes. When the younger son is killed in a robbery, the family succumbs to the impotence which characterized them at the beginning of the story.

Perhaps because Lonne Elder had a role in A Raisin in the Sun, there are some echoes of the earlier play. For example, the older son, like Walter Lee Younger, adopts the capitalistic values of America. But Elder does not evoke admiration for a hard-working family thwarted only by lack of money and by discrimination. Elder delineates a Black father who substitutes daydream/memory for action, who fears to subject himself again to humiliation by a White world, and who embezzles money to entertain a young woman, who deceives him. Elder portrays young males who drift indolently unless they are given responsibilities which interest and involve them. He presents a young woman as easily deceived as her father in her effort to find love. These, in short, are not strong characters. They are probably no better or worse than the characters in Bullins' world (or in the actual world beyond the stage). They do not proclaim that separation from Whites is advantageous for Blacks. Instead, they accept the separation from Whites as a fact. Whites are downtown. Sometimes Blacks must travel downtown to seek work, but the Black world is uptown.

Charles Gordone's controversial play, No Place to Be Somebody (1969), intended for a White audience, seems to stress the dangers potential whenever a member of one race imitates the values of a different race. If this is the thesis, then the values ascribed to White society seem to be greed, exploitation, corruption, and immorality, whereas the virtues ascribed to Blacks are naturalness of expression, basic honesty, generosity, and loyalty. 
It is surprising that these patterns should be inferred, since much of the play seems to be a mockery of the Black people and Black dreams.

No Place to Be Somebody is the story of Gabe Gabriel, a light-skinned actor/writer seeking employment in theater, and Johnny Williams, a darkskinned bar-owner and pimp, who is awaiting the return of his mentor, Sweets Crane, from prison so that the two can carve out a slice of the Mafia territory downtown. Like Walter Lee in Raisin and Theo, the older son, in Ceremonies, Johnny believes that virtue is doing others before they can do you. Surrounding Johnny in his Black world are Shanty, a White man who wants to be Black; Cora, a Black woman who wants to marry White; Dee, a White prostitute who loves Johnny; Evie, a Black prostitute who loves Dee or Johnny; and Melvin, a Black man who seeks a career in ballet. Like the characters in Raisin, each has a dream which reveals a conscious acceptance of particular values. Whereas Gabe, as narrator, mocks the efforts of Black people to assimilate themselves, he seeks a career in an integrated theater where he is rejected because, determined by the particular social mood, he is too fair-skinned or too dark-skinned. Above all, Gabe denies Johnny's contention that life in America must be a continuous war between Black and White. Shanty seeks in Black life and in Cora a naturalness of expression, a rhythm, a freedom of behavior different from the White life symbolized for him by his former wife, who resented the fact that, instead of protecting her from the lascivious pawings of his Black musician friends, he beat her. Shanty fails to perceive that Cora, despite her dark skin, has values identical with those of his former wife. Disillusioned by the behavior of Black men, she desires a White husband because she assumes that such a man will provide security, will treat her with respect, and will honor her morality. Recalling her early love for a Black youth, Dee seeks in the self-centered and ruthless Johnny a mature expression of that childhood dream. He represents for her a possibility for marriage and motherhood that she cannot find among Whites. Appalled by what he believes to be the ignorance and uncouthness of Blacks, Melvin seeks culture and refinement among White entertainers.

Most of the characters experience disillusionment. Unsuccessful in his effort to become a Black Mafia don, Johnny is killed by Gabe, who learns ironically that violent confrontation does seem to be the way of life in America. Distraught with the realization that dark-skinned Johnny is merely willing to exploit her and will never love her, Dee kills herself. Unwilling to be a stud or sex object at a White orgy, Melvin withdraws from ballet. Mary Lou Bolton, a naive White liberal, permits herself to be led by Johnny, a Black exploiter. Only Cora and Evie seem to realize dreams-Cora will move to Canada with her Canadian husband, a doctor, and Evie, retiring from prostitution, takes a job. 
There are ambivalences and ambiguities. Unlike Peterson and Hansberry, Gordone does not suggest that Blacks and Whites are identical except for skin color. On the other hand, he does provide unexpected similarities, such as the previously mentioned fact that Shanty's behavior corresponds to that of the Black husband whom Cora left, whereas Cora's values correspond to those of the White wife whom Shanty left.

The world that is pictured is nonetheless a Black world. The potential of integration is debatable. What is suggested, if I read the play correctly, is a need for Blacks to be willing to accept existence in a world populated by those whom Jones identified as the gang in The Toilet and the troops in The Slave-individuals who lack the cultural knowledge of Europeans but who constitute the Black population. Escape from such a world seems to lie only in education-which Gordone does not scrutinize as a solution-or in flight to a different country.

Almost as controversial as Gordone's play is Melvin Van Peeble's Ain't Supposed to Die a Natural Death (1973). Although I judge this work to be more a musical poem than a drama, it merits examination as an example of the continuing movement of Black playwrights into the examination of a separated Black life. The only White who appears in A Natural Death is a policeman who forces a young prostitute to submit to his sexual abuse and who kills a young Black. The continuous manipulation of the Black ghetto, however, is symbolized by a white-masked puppet-master who dangles the strings which control and are clutched by the ghetto Blacks.

What impresses one in the presentation, however, is that except for the concluding scenes, which emphasize the frustration which turns a postal clerk into an armed rebel and the brutality of the police (concluding scenes which seem tacked on for their appeal to a Black audience), most of the scenes focus on love: the desperate and generally unsuccessful search for love, and the various distortions of love. Unsuccessful in his efforts to persuade his sweetheart to give up prostitution, Country Boy becomes a Muslim minister. Seeking riches beyond those which young Junebug can offer, Tomboy turns to prostitution but is victimized by sexual abuse by the police. Big Titties (Dorothy), a buxom prostitute, vacillates between a life of exploitation by her pimp and the love offered by the Dyke. Although society does not approve, the quest for love by Funky Girl, a transvestite, is as genuine as that of others. She wants love, not merely sex: "The world is all slabs and broken needles unless someone cares for you." 8 Fatso considers suicide because he has been tricked and deserted by a woman he loves, but he receives no compassion from others. A waitress tells him,

Like the man said, what will be will be/

About the only time the man ever spoke

Without forked tongue. ${ }^{9}$ 
Deceived by perfume, the Blindman cries out for Funky Girl the Fag, whom he believes to be the woman of his dreams. The Drunk fails to evoke crowd sympathy with his story that loss of love is responsible for his condition. A convict recalls the dancing beauty of Lilly, the lover he killed. The only love rewarded is what may be the temporary or permanent reconciliation of Pops, the Drunk, with Missy, now free from Sunshine, who exploited her.

The world of A Natural Death is a world known to many Blacks, and the presentation is one intended for them. A Natural Death shows Black characters who validate the derogatory aspersions of White society that these beings are unfit. Van Peebles does not lessen the sting by showingas he might have-that such beings also populate White society. Nor does he advance sociological arguments to defend the behavior of the natives of the compassionless urban reservation. Nor does he concern himself with Blacks who live outside the ghetto experience.

Yet comparison between Blacks and Whites does emerge-not so much through Van Peebles' symbolic indication that Black behavior is manipulated by Whites but more by his individualizing and humanizing the stereotypes through their search for love.

In conclusion, as Black Arts drama developed during the final years of the 1960's, critics attacked the violence, the rhetoric, the emphasis upon separation of the races. If, however, one looks at presentations of dramas of Black experience since 1953 one discerns evolution: first, the Black playwright's vision of a world in which integration did not succeed but was honored because no other way of life seemed viable; then, the new vision of a world in which Blacks live and act apart from Whites.

While Black playwrights clung to the vision of a unified society, they emphasized the resemblances between Blacks and other Americans. As hope for that vision waned, Black playwrights have looked more closely and more critically at the individuals within the Black society. This pattern appears whether the playwright, consciously working as a Black Arts dramatist, argues the need to examine the internal problems of the Black community or whether-like Baldwin-he has merely chosen to write about a world he knows for an audience which also knows that world. Ironically, as Black dramatists examine their characters more critically, often they seem less polemical and more compassionate because, in the Black world, they perceive not only individuals searching for manhood and love but even more pathetic figures too impotent to search for manhood or to achieve a relationship of love. Because the dramatists are not romantic idealists, they offer neither placebos nor easy escapes. Much more softly than Richard Wright but with equal vigor, they say that the contemporary Black community lacks manliness and love. 
Is this need for manliness and love common to America in general? In his novels, Baldwin implies that it is. But the issue is unimportant to those Black dramatists who focus on the problems of love among Blacks. Is there overemphasis on the absence of love in Black communities? Perhaps. Nikki Giovanni suggests that possibility when, in "Nikki-Rosa," she argues that sociological biographies of Blacks fail to observe the power of love within Black families. Is there no need to picture Blacks who live outside the urban-Northern ghetto? Certainly, the Black playwrights of the past decade have ignored them. One can say only that, at this time, Black dramatists are not answering these questions. Presently, whether they propose realistic portraiture for the artistic entertainment of audiences which may be White or whether they propose realistic portraiture for Black audiences, the best-known Black playwrights are picturing an urban Northern community which is disparate from the White community and which is populated by those who need but lack the strengths which come from love.

\section{NOTES}

1 Take a Giant Step, in Black Drama in America, Darwin T. Turner, ed. (Greenwich, Conn.: Fawcett, 1971), Act II, Sc. 1, p. 346.

2 A Raisin in the Sun (New York: Signet/New American Library, 1966), Act II, Sc. 3, p. 97.

3 Hansberry, op. cit., Act III, p. 128.

4 Hansberry, op. cit., Act III, p. 125.

5 Dutchman, in Dutchman and The Slave (New York: Morrow, 1964), p. 35.

6 Ernst Toller, "Post-War German Drama," The Nation, 127 (November 7, 1928), p. 488.

7 Great Goodness of Life: A Coon Show, in Four Black Revolutionary Plays by LeRoi Jones (Indianapolis: Bobbs-Merrill, 1969), p. 58.

8 Ain't Supposed to Die a Natural Death (New York: Bantam, 1973), p. 73.

9 Van Peebles, op. cit., p. 45.

\section{DRAMA / SARAH WEBSTER FABIO}

\section{Saga of the Black Man (A Pageant-Drama)}

[Sarah Fabio's pageant-drama exemplifies the manner in which contemporary Afro-American playwrights blend Black cultural tradition with innovation. Structurally, the drama continues the tradition of the historical pageant, a form more frequently used in Black theater than in modern American theater as a whole. Always intended for a Black community audience, the pageant, created by such Blacks as Langston Hughes, W. E. B. 